\title{
MAKNA SEBUAH KEGAGALAN BISNIS DAN PEMBELAJARAN WIRAUSAHA: SEBUAH PEMBELAJARAN DARI PETANI MUDA DI ERA PANDEMI COVID 19
}

\section{THE MEANING OF BUSINESS FAILURE AND ENTREPRENEURIAL LEARNING: A LESSON FROM YOUNG FARMERS IN THE COVID 19 PANDEMIC ERA}

\author{
Gema Wibawa Mukti, Rani Andriani Budi Kusumo \\ Program Studi Agribisnis Fakultas Pertanian Universitas Padjadjaran \\ Email: gema.wibawa@unpad.ac.id \\ (Diterima 19-11-2020; Disetujui 29-12-2020)
}

\begin{abstract}
ABSTRAK
Pandemi telah menyebabkan terganggunya perekonomian secara global, tidak terkecuali Indonesia sebagai salah satu negara yang terdampak dari bencana pandemi covid 19 ini. Penelitian ini bertujuan untuk mempelajari petani muda dengan skala usaha kecil (pengusaha kecil) yang pada masa pandemi covid 19 mengalami kegagalan usaha dan mereka berusaha untuk menciptakan strategi baru dalam berbisnis atau menciptakan usaha baru sebagai bentuk adaptasi yang dilakukan oleh mereka dalam menghadapi pandemi. Penelitian ini menggunakan pendekatan secara kualitatif dan eksploratif. Informan dipilih secara sengaja (purposive), sesuai dengan pertimbangan peneliti, yaitu petani muda yang mengalami kegagalan dalam usahatani nya selama masa pandemi Covid 19. Informan dalam penelitian ini diambil sebanyak 5 (lima) orang, yaitu petani muda yang berusia 19-40 tahun dan mengalami kegagalan dalam usahatani nya selama masa pandemi covid 19. Hasil penelitian diharapkan dapat memberikan kontribusi terhadap proses pembelajaran kewirausahaan dari sebuah kegagalan bisnis. Dari sisi praktis, hasil yang diperoleh diharapkan dapat memberikan pengetahuan bagi seorang wirausahawan, bahwa pembelajaran adalah sesuatu yang berasal dari proses refleksi, sehingga dapat membantu mereka untuk memanfaatkan pengalaman yang dimiliki untuk meningkatkan kapasitas diri sehingga menjadi lebih baik pasca kegagalan bisnis.
\end{abstract}

Kata kunci : bisnis, kegagalan, petani muda, pandemi, wirausaha

\begin{abstract}
The pandemic has disrupted the global economy, including Indonesia as one of the countries affected by the COVID-19 pandemic. This study aims to study young farmers with small scale businesses (small entrepreneurs) who during the Covid 19 pandemic experienced business failures and they tried to create new strategies in doing business or create new businesses as a form of adaptation made by them in the face of the pandemic. This study uses a qualitative and exploratory approach. Informants were chosen purposively, in accordance with the researcher's considerations, namely young farmers who experienced failure in their farming during the Covid 19 pandemic. The informants in this study were taken as many as 5 (five) people, namely young farmers aged 19-40 years and experiencing failure in farming during the covid pandemic 19. The results are expected to contribute to the entrepreneurial learning process from a business failure. From the practical side, the results obtained are expected to provide knowledge for an entrepreneur, that learning is something that comes from a reflection process, so that it can help them to take advantage of their experiences to increase their capacity so that they become better after business failure.
\end{abstract}

Keywords: Business, entrepreneur, failure, pandemic, young farmers 


\section{PENDAHULUAN}

Umat manusia di seluruh dunia saat ini sedang menghadapi ancaman Virus Corona (Corona Virus Disease 2019). Semenjak kemunculan nya di kota Wuhan Tiongkok dan ditetapkan sebagai pandemi global oleh World Health Organization (WHO) pada tanggal 11 Maret 2020, Covid 19 menjadi pandemi yang membuat kehidupan masyarakat dunia berubah secara drastis. Beberapa negara di dunia, termasuk Indonesia melakukan langkah-langkah strategis untuk mengantisipasi penyebaran virus ini, agar penyebarannya tidak semakin meluas. Beberapa langkah tersebut diantaranya dengan melakukan Pembatasan Sosial Berskala Besar (PSBB), menjaga jarak satu sama lain (social distancing), dan meminta warganya agar selalu patuh dan disiplin dalam menerapkan protokol kesehatan.

Pandemi telah menyebabkan terganggunya perekonomian secara global, tidak terkecuali Indonesia sebagai salah satu negara yang terdampak dari bencana pandemi covid 19 ini (Aprilia \& Adianti, 2020). Berdasarkan laporan dari Gugus Tugas Covid 19 Republik Indonesia pada tanggal 13 Oktober 2020, jumlah kasus infeksi Covid 19 tercatat sebanyak 340.662 orang kasus positif,
263.296 orang sembuh, dan sebanyak 12.027 orang meninggal. Berbagai sektor perekonomian di Indonesia seperti sektor pariwisata dan ritel mengalami penurunan sebesar $40-60 \%$, secara tidak langsung hal ini juga mempengaruhi pada sektor pertanian sebagai sektor yang menyediakan bahan baku bagi industri ritel dan juga pariwisata (Muliati, 2020).

Produk pertanian adalah produk pangan yang dibutuhkan oleh masyarakat untuk meningkatkan imunitas tubuh dengan mengkonsumsi makanan yang sehat dan bergizi pada masa pandemi covid 19 ini. Kondisi ini seharusnya dapat mendorong permintaan produk pertanian karena kebutuhan produk pangan yang semakin meningkat, namun ternyata yang terjadi adalah sebaliknya. Distribusi produk pertanian dari sentra produksi di wilayah perdesaan menjadi terhambat ketika wilayah perkotaan melakukan PSBB atau Lockdown secara parsial. Selain itu, ekonomi di wilayah perkotaan yang semakin menurun dikarenakan ditutupnya pusat-pusat perekonomian menyebabkan banyak orang yang dirumahkan/dipecat dari pekerjaannya, sehingga daya beli masyarakat menjadi menurun. Kondisi ini menyebabkan menurunnya permintaan dan juga harga produk pertanian, bahkan 
di masa hari besar seperti momen Idul Fitri yang seharusnya menjadi momen permintaan produk pertanian yang paling tinggi.

Pandemi covid 19 telah menyebabkan banyak petani muda mengalami kerugian dalam usahanya, dimana hal ini menuntut mereka untuk re-adaptasi terhadap perubahanperubahan yang terjadi pasca pandemi. Kegagalan, hambatan dan tantangan dalam berwirausaha adalah sumber penting untuk pengembangan keterampilan, menjadi stimulus bagi seorang wirausahawan untuk mengembangkan diri dan usaha nya (Dias \& Martens, 2019; Cope, 2011; Politis, 2008; Ucbasaran et al, 2013). Proses belajar dari sebuah pengalaman adalah sebuah proses yang kompleks. Sikap negatif seorang wirausaha dapat mengganggu kapasitas individu dan bahkan dapat memberikan rasa trauma kepada dirinya sehingga akan berakibat pada kegagalan bisnis nya, Beberapa penelitian sebelumnya lebih fokus pada proses belajar wirausaha, terutama usaha kecil sebagai bidang penelitian yang masih perlu dikembangkan lagi (Blackburn \& Kovalainen, 2009).

Pada perspektif ini, pengembangan aspek teoritis mengenai pembelajaran kewirausahaan secara konstruktivis menjadi relevan. Proses adaptasi untuk menghadapi pandemi covid 19 adalah sesuatu yang baru bagi bidang ilmu kewirausahaan, Pengalaman dari sebuah kegagalan bisnis dapat merepresentasikan perspektif dinamis kewirausahaan, bagaimana seorang wirausahawan belajar untuk menghadapinya, sehingga dapat berdampak pada pengembangan diri maupun bisnisnya (Cope, 2011). Studi dalam makalah ini akan menyoroti empat kategori yang menghasilkan pembelajaran kewirausahaan dari seorang wirausahawan. Penelitian ini bertujuan untuk mempelajari petani muda dengan skala usaha kecil (pengusaha kecil) yang pada masa pandemi covid 19 mengalami kegagalan usaha dan mereka berusaha untuk menciptakan strategi baru dalam berbisnis atau menciptakan usaha baru sebagai bentuk adaptasi yang dilakukan oleh mereka dalam menghadapi pandemi.

Makalah ini akan dibagi ke dalam beberapa bagian, diantaranya adalah untuk menjelaskan tentang referensi teoritis tentang aspek pembelajaran kewirausahaan dan kegagalan bisnis, menjelaskan metodologi penelitian serta pada akhirnya akan disajikan hasil, pembahasan serta kesimpulan dari penelitian yang telah dilakukan. 
Berdasarkan kondisi dari petani muda di Indonesia, khususnya di sentra agribisnis di Provinsi Jawa Barat, maka peneliti tertarik untuk melihat bagaimana petani muda menghadapi masa pandemi covid 19 ini, menghadapi kegagalan dan tantangan yang muncul dalam proses bisnis mereka. Penelitian ini bisa dikatakan sebagai sebuah penelitian baru, karena dilakukan pada masa pandemi yang secara global telah mempengaruhi berbagai aspek perekonomian di berbagai sektor yang dapat "mengganggu" hajat hidup orang banyak.

\section{METODE PENELITIAN}

Penelitian ini menggunakan pendekatan secara kualitatif dan eksploratif. Pendekatan kualitatif merupakan salah satu cara untuk memahami sebuah fenomena sosial (Dwiastuti, 2017). Pendekatan secara eksploratif dilakukan untuk mendapatkan pemahaman mengenai perspektif dari informan. Memahami kegagalan bisnis yang dialami oleh petani memerlukan sebuah pemahaman yang mendalam, dengan pendekatan emosional yang rumit (Minello et al, 2014). Informan dipilih secara sengaja (purposive), sesuai dengan penilaian dari peneliti, yaitu petani muda yang mengalami kegagalan dalam usahataninya selama masa pandemi Covid 19. Penelitian dilakukan di sentra agribisnis Jawa Barat, yaitu Kabupaten Garut, yang dilaksanakan di Kecamatan Samarang dan Kecamatan Cisurupan. Informan dipilih berdasarkan kemudahan (viabilitas), yaitu mereka yang merasa nyaman untuk menjadi subjek penelitian, sehingga peneliti dapat mengungkapkan aspek kegagalan yang bersangkutan secara objektif.

Pemilihan petani muda sebagai informan dalam penelitian ditetapkan berdasarkan beberapa kriteria, diantaranya adalah: 1) Petani tersebut adalah pelaku usaha agribisnis berskala mikro atau kecil, 2) Petani adalah pengusaha yang bertindak sebagai pemilik usaha, pembuat keputusan utama dalam bisnis yang dimilikinya, 3) Petani telah menghentikan usahanya dan telah mencoba untuk berinvestasi pada usaha yang lain (pertanian/non pertanian). Pengumpulan data dilakukan dengan wawancara mendalam (depth interview) dan juga observasi mendalam terhadap informan.

Pengumpulan data dilakukan selama 3 (tiga) bulan, yaitu mulai dari bulan Agustus-Oktober tahun 2020. Informan dalam penelitian ini diambil sebanyak 5 (lima) orang, yaitu petani 
muda yang berusia 19-40 tahun dan mengalami kegagalan dalam usahataninya selama masa pandemi covid 19. Selanjutnya, setiap informan tersebut akan kami beri kode P1-P5, sesuai dengan jumlah informan sebanyak 5 (lima) orang. Analisis data dalam penelitian ini menggunakan analisis isi (content analysis). Analisis isi adalah teknik yang dapat digunakan untuk mengkaji perilaku manusia secara tidak langsung, yaitu melalui bentuk-bentuk komunikasi yang dapat dianalisis (Fraenkel et al, 1993). Langkah-langkah yang dilakukan dalam analisis data adalah: a) membaca hasil wawancara secara detail, b) menganalisis teks secara detail, c) menyoroti aspek-aspek utama dalam transkrip, sehingga dapat membentuk sebuah pemahaman berdasarkan periode atau peristiwa, d) penulisan analisis dengan menggunakan kutipan, dan e) menafsirkan data, membuat argumen dan membangun hubungan sebagai bukti yang dihasilkan sebagai sebuah pembelajaran kewirausahaan dari informan dalam menghadapi kegagalan bisnis. Dalam penelitian ini tidak digunakan alat analisis (software), karena alat analisis hanya melakukan proses penghitungan saja, tidak melakukan analisis itu sendiri, dan juga tidak menggantikan penggunaan metode untuk itu (Dias \& Martens, 2019).

\section{HASIL DAN PEMBAHASAN}

Penelitian ini pertama akan membahas tentang karakterisasi individu wirausaha dan usahatani yang dijalankannya. Setelah itu akan dilanjutkan dengan deskripsi singkat tentang pengalaman usaha mereka sebelumnya hingga mengalami kegagalan dalam usahanya tersebut. Pada bagian akhir, kegagalan usaha dari informan penelitian akan dianalisis secara bersamasama dilanjutkan dengan proses pembelajaran yang mereka lakukan untuk menghadapi kegagalan tersebut.

\subsection{Karakteristik Petani Muda Sebagai Wirausaha dan Aktivitas Bisnisnya}

Karakteristik petani muda sebagai seorang wirausaha muda pertanian, karakteristik bisnis mereka sebelum mengalami kegagalan akan digambarkan dalam Tabel 1. 
Tabel 1. Karakteristik Petani Informan

\begin{tabular}{|c|c|c|c|c|c|c|}
\hline 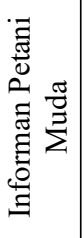 & 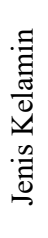 & 吾 & 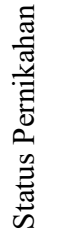 & $\begin{array}{l}\text { Pendidikan/Pelatihan } \\
\text { 1. Sebelum gagal } \\
\text { 2. Setelah memulai } \\
\text { bisnis baru }\end{array}$ & $\begin{array}{l}\text { Bisnis sebelum mengalami } \\
\text { kegagalan (Jenis Usaha, Lokasi } \\
\text { Usaha, Luas Lahan Penanaman, } \\
\text { Jejaring Bisnis) }\end{array}$ & $\begin{array}{l}\text { Bisnis setelah mengalami } \\
\text { kegagalan (Jenis Usaha, Lokasi } \\
\text { Usaha, Luas Lahan Penanaman, } \\
\text { Jejaring Bisnis }\end{array}$ \\
\hline P1 & $\mathrm{L}$ & 33 & $\mathrm{M}$ & $\begin{array}{l}\text { 1. Sarjana Ekonomi } \\
\text { 2. Sarjana Ekonomi }+ \\
\text { Pelatihan digital } \\
\text { marketing/E- } \\
\text { Commerce }\end{array}$ & $\begin{array}{l}\text { Budidaya+Penjualan } \\
\text { hortikultura (kentang, } \\
\text { daun), Kecamatan Samarang, } 1500 \\
\mathrm{M}^{2} \text {, Jejaring bisnis: bandar, } \\
\text { eksportir }\end{array}$ & 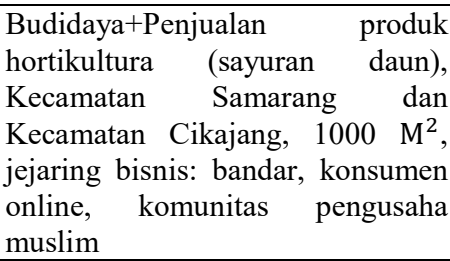 \\
\hline P2 & $\mathrm{L}$ & 39 & $\mathrm{BM}$ & $\begin{array}{l}\text { 1. Sarjana Pertanian } \\
\text { 2. Sarjana } \\
\text { Pertanian+Sekolah } \\
\text { Lapang Pertanian }\end{array}$ & $\begin{array}{l}\text { Budidaya+Penjualan produk } \\
\text { hortikultura (Tomat, sayuran daun, } \\
\text { domba), Kecamatan Samarang, } \\
1000 \mathrm{M}^{2} \text {, Jejaring bisnis: Bandar, } \\
\text { pasar tradisional, pasar domba } \\
\text { Rancabango Garut }\end{array}$ & $\begin{array}{l}\text { Budidaya+penjualan } \\
\text { hortikultura (sayuran daun), } \\
\text { Kecamatan Samarang dan } \\
\text { Kecamatan Cisurupan, } 1280 \mathrm{M}^{2} \text {. } \\
\text { Jejaring bisnis : Perumahan- } \\
\text { perumahan di wilayah Kota dan } \\
\text { Kabupaten Garut }\end{array}$ \\
\hline P3 & $\mathrm{L}$ & 35 & $\mathrm{M}$ & $\begin{array}{l}\text { 1. Sekolah Menengah } \\
\text { Atas } \\
\text { 2. Sekolah Menengah } \\
\text { Atas }\end{array}$ & $\begin{array}{l}\text { Budidaya+Penjualan } \\
\text { hortikultura (sayuran daun, Buncis, } \\
\text { horenzo), Kecamatan Samarang, } \\
2000 \quad \mathrm{M}^{2} \text {, Jejaring bisnis: } \\
\text { Eksportir, Pasar Modern }\end{array}$ & $\begin{array}{l}\text { Penjualan } \quad \text { Kopi, } \\
\text { Samarang, } \quad 50-100 \quad \mathrm{Kg} / \text { bulan, } \\
\text { Jejaring bisnis: } \text { Pasar online }\end{array}$ \\
\hline P4 & $\mathrm{L}$ & 40 & $\mathrm{M}$ & $\begin{array}{l}\text { 1. Sekolah Menengah } \\
\text { Atas } \\
\text { 2. Sekolah Menengah } \\
\text { Atas+Pelatihan } E \text { - } \\
\text { commerce+Pelatihan } \\
\text { Manajemen } \\
\text { Usahatani+Pelatihan } \\
\text { Copywriting } \\
\end{array}$ & $\begin{array}{l}\text { Budidaya+Penjualan produk } \\
\text { hortikultura (kol, wortel, kentang), } \\
\text { Kecamatan Cisurupan, } 5000 \mathrm{M}^{2} \text {, } \\
\text { Jejaring bisnis: bandar, eksportir, } \\
\text { pasar modern }\end{array}$ & $\begin{array}{l}\text { Budidaya+penjualan (trading) } \\
\text { produk hortikultura (Jeruk lemon, } \\
\text { jeruk garut), Kecamatan } \\
\text { Cisurupan, 1000 } \mathrm{M}^{2} \text {, Jejaring } \\
\text { bisnis: Pasar online, komunitas } \\
\text { hidup sehat di Garut dan Bandung }\end{array}$ \\
\hline P5 & $\mathrm{L}$ & 32 & $\mathrm{M}$ & $\begin{array}{l}\text { 1. Ahli Madya (D3) } \\
\text { Pertanian } \\
\text { 2. Ahli Madya (D3) } \\
\text { Pertanian+Sekolah } \\
\text { Lapang Pertanian }\end{array}$ & $\begin{array}{l}\text { Budidaya+Penjualan } \\
\text { hortikultura (Cabai), Kecamatan } \\
\text { Cisurupan, 2200 } \mathrm{M}^{2} \text {, Jejaring } \\
\text { bisnis: Pasar Induk Cipinang, } \\
\text { bandar }\end{array}$ & $\begin{array}{l}\begin{array}{l}\text { Budidaya+penjualan } \\
\text { hortikultura }\end{array} \\
\text { daun)+Penjualan } \\
\text { (sayuran } \\
\text { kesehatan (masker, face shield), } \\
\text { Kecamatan Cisurupan, 1500 } \mathrm{M}^{2} \text {, } \\
\text { Jejaring Bisnis: Pasar online, } \\
\text { bandar, Dinas Kesehatan } \\
\begin{array}{l}\text { Kabupaten Garut, masyarakat } \\
\text { umum }\end{array}\end{array}$ \\
\hline
\end{tabular}

Keterangan: P1-P5 = Petani Informan No 1-5, L = Laki-laki, M = Menikah, BM = Belum Menikah Sumber : Data Primer (diolah)

\subsection{Pengalaman Petani Informan}

\section{Mengenai Kegagalan Usaha}

Pada bagian ini akan dijelaskan secara singkat mengenai pengalaman bisnis para petani informan sebelum mengalami kegagalan pada masa pandemi covid 19. a. Petani Informan $1(\mathrm{P} 1)$

Petani informan pertama adalah seorang sarjana ekonomi yang memilih pertanian sebagai bidang usaha yang digelutinya: "Saya yakin pertanian adalah usaha yang sangat menguntungkan, karena tiap orang 
pasti makan!". Beberapa pernyataan informan sebelumnya menunjukkan bahwa dia memiliki optimisme tinggi dalam menjalankan bisnis pertanian : "[...] Akang kapan terakhir makan? pasti tadi pagi sarapan dulu, ataupun kl tidak, kemarin pasti makan malam, pasti tidak ada orang yang tidak makan lebih dari 2 hari”. Informan memiliki keyakinan bahwa permintaan produk pertanian pasti akan selalu ada selama manusia masih memerlukan makanan, dan itu artinya selamanya. Petani informan mengalami kesulitan ketika permintaan produknya berkurang atau bahkan berhenti sama sekali. Hal ini bukan karena masyarakat/manusia sudah berhenti makan, namun pasar yang biasa menerima produknya belum dapat diakses untuk sementara, karena adanya PSBB atau karantina wilayah. Hal ini tampaknya belum pernah diantisipasi sebelumnya oleh petani informan, karena memang belum pernah terjadi sebelumnya, sehingga membuat bisnis nya mengalami kerugian yang besar dan harus berhenti untuk sementara, karena belum ada pasar alternatif untuk sementara ini. Hal ini adalah kegagalan bagi petani informan, [...] "saya harus berhenti dulu, agar hutang saya tidak semakin besar".

b. Petani Informan 2 (P2)

Petani informan kedua memiliki keinginan besar untuk menjalankan usaha sejak mahasiswa, "[...] saya sudah mulai bertani dari semester 7 , ingin membuktikan ke teman-teman bahwa bisnis dalam bidang pertanian juga bisa menjadi sukses". Petani informan (P2) memulai bisnis pertanian dengan biaya yang berasal dari dana pribadi, yang berasal dari hadiah-hadiah lomba yang diikutinya selama menjadi mahasiswa. "[...] Saya memutuskan untuk menggunakan dana investor untuk mengembangkan usaha saya". Namun penggunaan dana investor ini tidak berjalan dengan baik, karena kesulitan pemasaran produk pada masa pandemi covid 19, sehingga bisnisnya mengalami kerugian. "[...] Saya tidak siap menghadapi covid 19, karena saya terlalu semangat dalam menjalankan bisnis ini, sehingga tidak memperhitungkan masalah-masalah yang mungkin muncul dalam bisnis ini”.

c. Petani Informan 3 (P3)

Petani informan ketiga menjalani bisnis pertanian karena faktor orang 
tua yang berprofesi sebagai petani, dan juga masyarakat di sekitarnya yang juga mayoritas adalah petani : [...] Saya bisnis pertanian karena dari kecil sudah terbiasa diajak oleh orang tua untuk ikut bertani. Pandemi covid 19 telah membuat pasar utama dari petani informan ini menghentikan sementara permintaannya, sehingga secara otomatis usahanya pun menjadi ikut berhenti. [...] Saya kurang dapat mengatur keuangan dengan baik, tidak terbiasa untuk menyisihkan uang untuk investasi bagi usaha saya sendiri, sehingga ketika kondisi seperti ini, sulit bagi saya untuk mempertahankan bisnis tetap berjalan".

d. Petani Informan 4 (P4)

Petani informan keempat menjalani bisnis pertanian karena faktor keturunan. Informan (P4) meneruskan bisnis yang diwariskan oleh ayahnya. Faktor keluarga yang merupakan petani dan juga teman-teman satu desa yang juga menjadi petani membuat informan percaya diri dalam menjalankan bisnisnya tersebut. [...] " pasar sudah ada, pengalaman ada, bertani sudah menjadi pekerjaan saya sehari-hari, bahkan semenjak saya kecil”. Kegagalan bisnis dari P4 terjadi karena adanya perubahan komoditas yang diminta oleh pasar karena adanya pandemi covid 19. Kondisi ini ternyata tidak dapat diantisipasi dengan baik oleh informan : [...] "saya coba mencari pasar lain untuk produk saya saat ini, karena memang saya belum memiliki keahlian dalam budidaya lemon, namun ternyata saya malah tidak dapat menjual produk saya yang lama.". Ternyata hal ini menyebabkan kegagalan bisnis, sehingga usaha dari (P4) sempat vakum selama 4 bulan (Juni-September).

e. Petani Informan 5 (P5)

Petani informan kelima memiliki bisnis pertanian karena menikah dengan istri yang berasal dari Garut : [...] Istri saya orang Garut, jadi setelah menikah saya berhenti dari pekerjaan saya di Bandung dan menjadi petani sampai sekarang". Pandemi covid 19 telah menyebabkan hasil panen cabai pada saat hari raya Idul Fitri tidak terserap, karena masyarakat tidak merayakan hari raya seperti biasa karena adanya berbagai keterbatasan yang disebabkan oleh pandemi covid 19 : [...]" Saya sudah menanam mulai dari bulan sebelas tahun kemarin (November 2019) 
untuk dijual pada hari raya Idul Fitri tahun ini, tapi ternyata permintaan tidak ada, sehingga produk saya tidak terjual".

\subsection{Makna Kegagalan dan Proses Pembelajaran Wirausaha dari Petani Muda}

Kegagalan merupakan sebuah hal yang biasa, bahkan sangat biasa terjadi dalam sebuah bisnis, baik itu usaha bisnis baru maupun lama. Kegagalan atau keberhasilan bisnis sangat dipengaruhi oleh lingkungan, terutama lingkungan ekonomi secara global yang saat ini sangat terpengaruh roda perputaran nya akibat pandemi covid 19. Dalam proses bisnis, seorang wirausaha akan selalu menghadapi berbagai tantangan, seperti misalnya kondisi ekonomi, persaingan, perubahan konsumen, teknologi dan juga bencana alam, atau mungkin juga kesulitan yang ditimbulkan oleh diri sendiri, seperti kesalahan manajemen, human eror, dan sebagai nya (Toumi \& Smida, 2018).

Berdasarkan penelitian yang pernah dilakukan oleh peneliti pada tahun 2016 terhadap lulusan Fakultas Pertanian UNPAD yang menjadi petani baru, menjelaskan bahwa mereka umumnya tidak bertahan lebih dari 3 (tiga) tahun dalam bisnisnya. Secara umum, mereka berpindah ke sektor usaha lainnya atau memutuskan untuk bekerja di sektor non pertanian. Kegagalan dalam sebuah bisnis diakibatkan oleh berbagai faktor. Sebagian pengusaha baru gagal dalam menjalankan bisnisnya karena mereka tidak memiliki kompetensi manajerial dan pengalaman dalam bisnis tersebut (Kennedy et al, 2006; Minello et al, 2014), sedangkan faktor lainnya adalah karena adanya tekanan emosional dalam diri mereka sehingga menjadi tidak optimal dalam menjalankan usahanya tersebut (Dias \& Martens, 2019). Perubahan ekstrim yang terjadi selama masa pandemi covid 19 telah membuat petani mengalami tekanan emosional, sehingga mereka tidak dapat mengikuti perubahan tersebut sehingga mereka tidak mampu bertahan di dalamnya. Kegagalan bisnis merupakan aspek penting dalam kewirausahaan yang harus dipelajari, namun definisi kegagalan yang berbeda-beda membuatnya sulit untuk dianalisis (Robinson, 2007).

Apa yang dimaksud dengan kegagalan? Secara sederhana, kegagalan adalah ketidakberhasilan. Berdasarkan Kamus Besar Bahasa Indonesia, gagal adalah tidak berhasil (KBBI, 2019). Kegagalan identik dengan tidak 
tercapainya target yang telah ditetapkan sebelumnya (Jannah, 2015). Oleh karena itu, selalu terdapat kriteria atau parameter untuk menentukan apakah sebuah bisnis itu berhasil atau gagal, yaitu dilihat dari sisi ketercapaian atau ketidaktercapaian sebuah usaha terhadap target yang telah ditetapkan sebelumnya. Pada beberapa literatur telah dijelaskan istilah kegagalan bisnis, kerugian, kebangkrutan, pengurangan dan lain sebagai nya (Mellahi \& Wilkinson, 2004).

Dalam makalah ini, kegagalan bisnis akan dipahami sebagai mengubah proses bisnis karena berbagai macam alasan, mengalihkan bisnisnya ke dalam bentuk lain, sehingga pengusaha tersebut dapat memulai bentuk bisnis yang baru. Kegagalan bisnis bagi individu pengusaha bersifat kompleks dan paradoks, karena pada prinsipnya individu pengusaha dan perusahaan/usaha mereka sangat terkait erat (Ucbasaran et $a l, 2013)$. Keputusan bisnis tentu akan terkait dengan karakteristik, pengetahuan dan kemampuan dari pengusaha selama proses bisnis berlangsung. Cope (2011) menjelaskan bahwa kegagalan lahir dari sebuah proses yang kompleks, bukan terjadi dari proses yang parsial atau berdiri sendiri. Sebuah perumpaan bagi seorang wirausaha yang gagal, ditandai dengan tiga fase yang satu sama lain saling terkait: 1) fase kegagalan, dimana individu wirausaha harus "mengeluarkan" biaya kegagalan (finansial, sosial dan psikologis), 2) fase refleksi diri, dimana seorang wirausaha berupaya untuk belajar dan memahami makna dari kegagalan yang dialaminya, 3) Fase pemulihan, dimana wirausaha berusaha untuk pulih dan terus mencari cara untuk bangkit, melalui segala pengetahuan dan kemampuan yang dimiliki nya. Memahami ketiga fase ini dalam diri seorang wirausaha menjadi sangat penting, karena mengubah pengalaman para pengusaha/petani muda menjadi sebuah pembelajaran bagi kita semua (Cope, 2005)

$$
\text { Untuk mempelajari makna }
$$
kegagalan dan proses pembelajaran yang dilakukan oleh seorang wirausaha dari kegagalannya tersebut, data dari kelima informan akan dikelompokkan dan dianalisis secara bersama-sama.

\subsubsection{Kegagalan Dalam Bisnis Pertanian}

Berikut akan disajikan definisi kegagalan bisnis menurut para petani informan yang diperoleh dari hasil wawancara secara mendalam. 
Tabel 2. Pernyataan Informan Mengenai Kegagalan Bisnis

P1 "Saya kurang mempersiapkan diri untuk menghadapi hal-hal yang tidak terduga (pandemi covid

P1 19), terlalu berfokus pada penambahan pohon (produksi), sehingga hutang juga bertambah"

P2 "Tanggung jawab kepada investor harus diselesaikan, ternyata manajemen usaha saya belum bagus, sehingga hal ini terjadi pada saya"

P3 "Saya harus belajar lagi mengatur keuangan usaha, masih sering tercampur dengan kebutuhan pribadi, belum bisa menabung (investasi)"

P4 "Jadi pengusaha harus nurut kepada konsumen, kalau tidak nurut, hancur lah bisnis kita"

P5 "Bisnis harus punya saku lebih dari satu (punya alternatif lain ketika satu produk gagal), agar bisa tetap bertahan pada saat pandemi seperti ini”

Sumber : Data Primer (data telah ditranslate dari bahasa sunda ke bahasa Indonesia)

Pernyataan-pernyataan informan yang disajikan dalam Tabel 2 memperlihatkan bahwa kegagalan bisnis terkait dengan proses bisnis yang dijalankan oleh para petani informan. Kinerja bisnis menjadi faktor penting bagi seorang pengusaha, apakah bisnisnya tersebut akan bertahan atau mengalami kematian (Grande et al, 2011). Dari pengamatan pada kelima informan, terlihat bahwa kebutuhan untuk menganalisis proses belajar mereka menjadi nyata, sebagai sebuah fase yang saling terkait satu sama lain (Cope, 2011).

Kegagalan bagi para petani informan memiliki pengaruh kepada pribadi, keluarga dan juga secara tidak langsung kepada petani lainnya. Secara keuangan, mereka mengalami kerugian yang tidak sedikit, seperti pada petani P2, yang harus mengganti kerugian dari para investor, selain kerugian yang dialami oleh petani tersebut secara pribadi. Untuk petani P1, kerugian finansial telah menjadi tantangan nyata, yaitu untuk membayar hutang-hutang yang disebabkan oleh kegagalan bisnis. Bagi petani (P3), kegagalan dalam mengatur keuangan bisnis sama dengan kegagalan dalam mengelola bisnis itu sendiri. Kegagalan pengelolaan keuangan menjadi aspek yang paling sering ditemukan dalam penelitian mengenai kegagalan bisnis (Longenecker et al, 1999). Dalam fase "kegagalan" ini, semua informan menyatakan pernah mengalami masa-masa sulit dan stres bagi diri mereka dan juga keluarga. Masalah bisnis tentu akan berdampak pada pengusaha sebagai seorang pribadi dan juga sebagai seorang professional (Cope, 2011). Petani (P3) menjelaskan bahwa: " Saya sering bertengkar dengan istri masalah keuangan, karena saya seringkali menggunakan uang yang bukan untuk peruntukannya”. Petani (P5) menyatakan bahwa: "Istri saya sempat meninggalkan saya selama satu minggu, karena waktu itu saya benar-benar tidak 
memiliki uang". Pernyataan-pernyataan ini memperlihatkan stress yang disebabkan oleh ketidaksepakatan dan juga kekecewaan yang muncul dari orang-orang terdekat dari para petani informan.

Secara psikologis, kegagalan dalam usahanya telah membebani diri mereka, baik itu sebagai pengusaha maupun sebagai pribadi. Kegagalan dalam berbisnis tidak hanya membawa kerugian secara ekonomi, namun juga memberikan dampak psikologis pada aspek kehidupan pribadi mereka, dan cara mereka memandang dunia/lingkungan sekitarnya menjadi sedikit berbeda (Minello et al, 2014). Namun demikian, para petani informan ini adalah para entrepreneur yang dinamis dan selalu proaktif untuk menghadapi sebuah permasalahan, mereka memilih untuk berinvestasi untuk membangun usahanya lagi, meskipun hal tersebut "memaksa" mereka untuk berkorban lebih banyak untuk mendapatkan modal untuk usaha barunya. Usaha untuk memendam rasa sakit karena sebuah kegagalan merupakan sebuah hal yang sangat penting bagi pemulihan emosional (Shepherd et al, 2009). Cope (2011) menjelaskan bahwa biaya kegagalan (emosional dan sosial) merupakan biaya untuk sebuah proses pembelajaran seorang wirausaha. Proses ini memberikan kontribusi terhadap proses penyembuhan terhadap mereka yang mengalami sebuah kegagalan.

$$
\text { Para petani informan selalu }
$$
berusaha untuk memberi makna terhadap kegagalan yang menimpa mereka, terutama pada masa pandemi covid 19 . Proses ini telah memberikan kemungkinan kepada mereka untuk pulih atau kembali kepada keadaan mereka sebelumnya. Dalam penelitian ini, ditemukan bahwa pemulihan berasal dari dukungan teman, pasangan hidup dan juga anggota keluarga lainnya. Interaksi sosial dengan lingkungan sekitar menjadi hal penting bagi petani informan untuk mengatasi segala kesulitan yang mereka hadapi. Selama proses pembelajaran, pengetahuan, kegagalan itu sendiri dan berbagai tindakan untuk menghadapi kegagalan tersebut adalah saling berhubungan satu sama lain. Oleh karena itu, perlu diapresiasi cara petani informan melihat sesuatu yang baru sebagai sesuatu yang prospektif bagi mereka di masa yang akan datang. 


\subsubsection{Proses Pembelajaran Wirausaha Petani Muda}

Dalam makalah ini, kami mencoba untuk memahami proses belajar seorang pengusaha yang terbentuk melalui konstruksi dari sebuah pengalaman. Seseorang tentu akan belajar dari berbagai pengalaman yang akan membentuk karakter diri yang unik. Seorang pengusaha akan memanfaatkan pengetahuan yang dia dapatkan dari sebuah kejadian atau pengalaman sebelumnya, untuk kemudian dia kembangkan untuk mendapatkan sesuatu yang lebih baik di masa yang akan datang. Sebuah pembelajaran yang tentunya akan sangat dipengaruhi oleh proses bisnis, jaringan bisnis, serta informasi-informasi yang dapat diakses oleh seorang pengusaha dalam perjalanan bisnisnya (Cope, 2003).

Proses belajar seorang wirausaha akan sangat dipengaruhi oleh berbagai pengalaman yang didapatnya dalam proses bisnis, baik itu pengalaman yang positif maupun negatif (Minniti \& Bygrave, 2001). Cope (2011) menjelaskan empat kategori (dimensi) pembelajaran untuk menghadapi sebuah kegagalan. Kategori pertama adalah pendekatan yang fokus pada proses belajar "diri sendiri", menyadari kelemahan diri yang menyebabkan kegagalan dalam bisnisnya, Kategori kedua adalah pendekatan yang fokus pada proses belajar "bisnis dan kegagalan yang menyertainya”, memahami kelemahan yang terdapat dalam proses dan strategi bisnis yang telah dilakukan sebelumnya, sehingga seorang wirausaha dapat melakukan perbaikan/redefinisi dari proses dan strategi bisnis yang akan digunakan dalam perusahaannya kemudian. Kategori ketiga adalah pendekatan yang fokus pada proses belajar "jaringan kolaborasi bisnis/sosial", melihat kembali sifat dan pengelolaan jejaring bisnis yang telah ada sebelumnya, baik itu internal maupun eksternal perusahaan. Kategori keempat adalah pendekatan yang fokus pada proses belajar "manajemen bisnis", sehingga seorang wirausaha dapat lebih adaptif dalam menghadapi berbagai kendala dalam bisnisnya dan menjadi lebih peka terhadap berbagai potensi kegagalan (Cope, 2005).

Proses belajar seorang wirausaha dimulai dari diri sendiri hingga pengelolaan bisnis, sehingga dia lebih siap menghadapi berbagai macam perubahan yang pasti akan selalu terjadi dalam dunia bisnis, terutama dalam bidang agribisnis yang memiliki 


\section{MAKNA SEBUAH KEGAGALAN BISNIS DAN PEMBELAJARAN WIRAUSAHA: \\ SEBUAH PEMBELAJARAN DARI PETANI MUDA DI ERA PANDEMI COVID 19 \\ Gema Wibawa Mukti, Rani Andriani Budi Kusumo}

karakteristik unik. Produk agribisnis sangat tergantung kepada alam, sehingga memiliki risiko tinggi dalam realisasi bisnisnya. Kondisi ini tentu akan melahirkan proses bisnis yang unik dan juga karakter wirausaha yang tentunya memiliki keunikan tersendiri. Berikut akan dijelaskan mengenai metodologi yang akan digunakan dalam penelitian ini.

Setiap individu memiliki caranya masing-masing untuk memanfaatkan kegagalan bisnis sebagai kesempatan untuk memperkuat diri mereka melalui pengalaman hidup dan pembelajaran dari kegagalan bisnis yang dialaminya.
Selanjutnya akan dipelajari dimensi pembelajaran kewirausahaan dari kelima informan penelitian, yang dibangun dengan menafsirkan makna pengalaman mereka. Kegagalan bisnis adalah sebuah konteks permasalahan yang kompleks dan nyata, dimana petani informan sebagai seorang pengusaha berusaha untuk mengembangkan kemampuan manajerial, seperti pengetahuan, teori, keterampilan dan kemampuan yang terkait bisnis nya, dan mengetahui bagaimana untuk bertindak untuk menyikapi kegagalan bisnis (Cope, 2003; Minello et al, 2014).

Tabel 3. Proses Memahami Diri Sendiri Bagi Petani Informan

Proses Pemahaman Diri Sendiri

P1 Saya terlalu menganggap remeh sebuah perencanaan usaha. Saya akui seringkali saya menganggap remeh kondisi yang ada, dan terlalu percaya diri dengan kemampuan saya. [...] Saya terlalu yakin dengan apa yang sedang saya kerjakan, padahal Allah yang menentukan keberhasilan, seharusnya saya lebih mempersiapkan segala sesuatu nya dengan lebih rinci". [...] Covid memberi saya pelajaran, ada hal-hal yang di luar kekuasaan anda, dan ini menjadi pengalaman baru bagi saya dan keluarga.

P2 Manajemen risiko adalah sesuatu yang penting bagi sebuah usaha, [...] jujur ini pengalaman pertama, barang (hasil panen) tidak bisa masuk ke pasar. Apabila Covid adalah penyebab hancurnya bisnis saya, harusnya semua juga hancur, tapi ternyata ada bahkan banyak yang lain tetap bertahan.[...] sepertinya ada yang salah dengan pengelolaan usaha, harus tertulis, agar saya tidak lupa pada saat di lapangan.

P3 [...] "Mengelola keuangan pribadi ternyata benar-benar berbeda dengan mengelola keuangan usaha". Saya harus mulai untuk memisahkan keuangan usaha dan bisnis, menyisihkan uang untuk investasi, saya harus melakukan nya.

P4 [...] "Jadi pengusaha harus banyak bertanya, tidak cukup hanya dengan pengalaman saja". Bisnis pertanian ternyata bukan sebuah rutinitias, namun sebuah tantangan baru yang selalu datang di setiap musim nya, jadi saya harus belajar terus, agar dapat mengatasi tantangan-tantangan baru di depan. [...] "harus yakin dapat bertahan dan bangkit kembali, asal terus ikhtiar dan berdoa.

P5 [...] "Saya selalu khawatir ketika harus mencoba sesuatu yang baru, takut salah dan gagal". Ingin nya saya kerja di kantor, tapi itu bukan bidang saya, itu bukan sesuatu yang saya sukai. [...] "Saya harus memulai lagi usaha, mulai mencari pinjaman modal, kalau tidak seperti itu, keluarga saya makan apa nanti”.

Sumber : Data Primer (data telah ditranslate dari bahasa sunda ke bahasa Indonesia) 
Petani sebagai seorang individu dan sebagai pemilik bisnis akan terkait dengan erat (diadopsi dari Ucbasaran et al, 2013). Artinya proses pembelajaran bagi seorang petani, selain berusaha untuk memahami diri sendiri, mereka juga akan berusaha untuk mengidentifikasi kekuatan dan kelemahan bisnis mereka, meningkatkan keterampilan dan kemampuan mereka dalam aspek manajerial usaha. Petani sebagai seorang pengusaha juga mulai membuka diri atas kesempatan bisnis yang lain, minat dalam jaringan bisnis yang lain. Mereka mulai melihat kebutuhan pihak lain dalam jejaring bisnisnya, seperti pasar/pelanggan, petani lainnya, pemasok, pemangku kebijakan, Perguruan tinggi dan lembaga keuangan. Peneliti melihat bahwa hal ini merupakan sebuah proses pembelajaran bagi petani, bagaimana mereka mencoba untuk bangkit dan mencoba sesuatu yang baru dalam aktivitas bisnis nya.

\section{Tabel 4. Proses Pembelajaran Bisnis dan Jejaring Bisnis Bagi Petani Informan}

\begin{tabular}{|c|c|c|}
\hline \multirow[t]{2}{*}{$\mathrm{P} 1$} & $\begin{array}{l}\text { Proses } \\
\text { Pembelajaran } \\
\text { Bisnis dari } \\
\text { kegagalan } \\
\text { yang dialami }\end{array}$ & $\begin{array}{l}\text { [...] "Tidak ada masalah, hidup terus berlanjut, saya masih punya teman dan } \\
\text { keluarga yang bisa membantu saya untuk mendapatkan modal usaha. } \\
\text { Permasalahannya saya belum mempunyai alternatif pasar yang memadai, saya } \\
\text { harus mempersiapkan hal tersebut. [...] "Saya belajar usahatani secara otodidak, } \\
\text { tidak pernah kursus bertani". [...] Gara-gara pandemi, saya lebih berhati-hati dalam } \\
\text { membuat sebuah keputusan. }\end{array}$ \\
\hline & $\begin{array}{l}\text { Proses } \\
\text { Pembelajaran } \\
\text { Jejaring Bisnis }\end{array}$ & $\begin{array}{l}\text { Zaman sekarang, online itu sudah menjadi kebutuhan, }[\ldots] \text { "saya harus belajar } \\
\text { pemasaran online, berusaha untuk mendapatkan pembeli baru, sehingga hasil panen } \\
\text { akan selalu terjual habis". Dalam masa pandemi ini silaturahmi harus lebih } \\
\text { diperkuat, }[\ldots] \text { "saya harus lebih sering ketemu dengan teman-teman, memperluas } \\
\text { jaringan, siapa tau mereka bisa membantu pemasaran hasil panen kebun saya". }\end{array}$ \\
\hline \multirow{2}{*}{$\mathrm{P} 2$} & $\begin{array}{l}\text { Proses } \\
\text { Pembelajaran } \\
\text { Bisnis dari } \\
\text { kegagalan } \\
\text { yang dialami }\end{array}$ & $\begin{array}{l}\text { [...] "Bagaimana memulai lagi usaha?" Pertanyaan yang sering muncul dalam } \\
\text { pikiran saya". Butuh keberanian bagi saya untuk memulai lagi usaha, } \\
\text { mengembalikan lagi kepercayaan investor. Perencanaan dan pemilihan mitra } \\
\text { menjadi yang utama saat ini, karena kedua hal tersebut adalah kekuatan yang saya } \\
\text { butuhkan untuk kembali berbisnis. [...] "perencanaan yang buruk dan mitra yang } \\
\text { kurang bisa diandalkan adalah kelemahan dalam bisnis. }\end{array}$ \\
\hline & $\begin{array}{l}\text { Proses } \\
\text { Pembelajaran } \\
\text { Jejaring Bisnis }\end{array}$ & $\begin{array}{l}\text { [...] "Selama ini saya melihat petani lain adalah saingan dalam usaha, yang akan } \\
\text { "mengganggu"bisnis saya". Namun ternyata menjalin jejaring pada masa pandemi } \\
\text { adalah sesuatu yang harus dilakukan agar bisnis dapat tetap survive. [...] } \\
\text { "Alhamdulillah pemasaran pada masa sulit ini dibantu oleh teman-teman petani } \\
\text { yang lain, saya harus terus memperluas silaturahmi,dengan petani yang lain dan } \\
\text { juga teman-teman alumni yang berusahatani". }\end{array}$ \\
\hline \multirow{2}{*}{ P3 } & $\begin{array}{l}\text { Proses } \\
\text { Pembelajaran } \\
\text { Bisnis dari } \\
\text { kegagalan } \\
\text { yang dialami }\end{array}$ & $\begin{array}{l}\text { [...] "mungkin pandemi ini adalah cara Allah menegur saya, mengingatkan saya } \\
\text { untuk berikhtiar lebih baik, belajar lebih banyak, jangan "ujub" oleh pengalaman } \\
\text { yang dimiliki". [...] Pasti saya akan kembali bertani, tapi harus mau belajar, agar } \\
\text { pengelolaan usaha nya lebih profesional. }\end{array}$ \\
\hline & $\begin{array}{l}\text { Proses } \\
\text { Pembelajaran } \\
\text { Jejaring Bisnis }\end{array}$ & $\begin{array}{l}{[\ldots] \text { "saya bukan sarjana, tapi InshaAllah dengan rajin, saya bisa berbisnis seperti }} \\
\text { seorang sarjana. Kebutuhan pemasaran secara online pada masa pandemi telah } \\
\text { menjadi sesuatu yang penting bagi seorang pengusaha", }[\ldots] \text { saya harus memiliki } \\
\text { pasar yang luas, tidak hanya terbatas pada buyer yang sudah ada, saya harus belajar } \\
\text { pemasaran secara online". }\end{array}$ \\
\hline P4 & $\begin{array}{l}\text { Proses } \\
\text { Pembelajaran }\end{array}$ & $\begin{array}{l}\text { [...] "Petani seringkali menanam karena kebiasaan, atau karena melihat petani lain } \\
\text { nya menanam tanaman tersebut". Petani sering kesulitan pada saat harga turun, atau }\end{array}$ \\
\hline
\end{tabular}




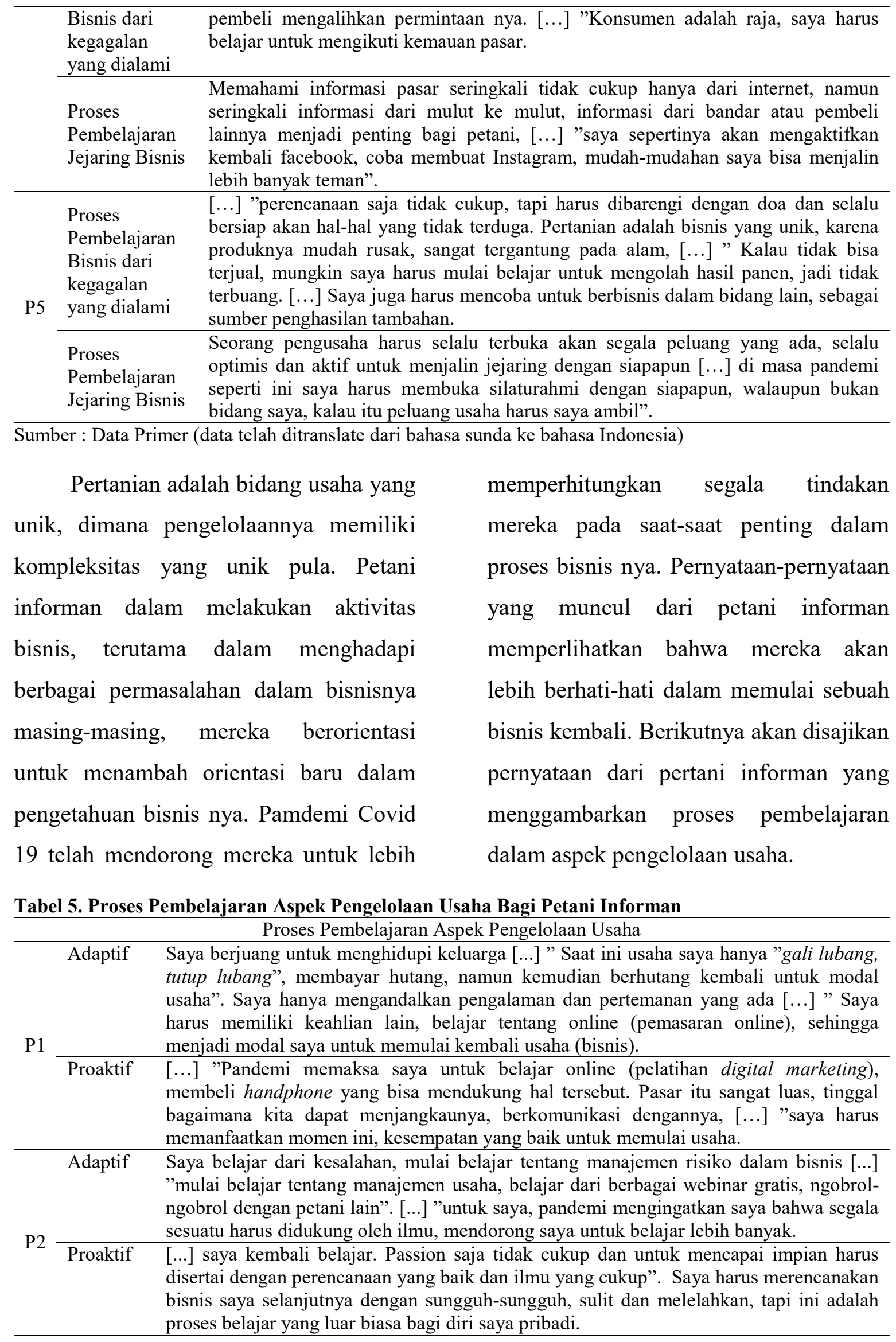




\begin{tabular}{|c|c|c|}
\hline \multirow{2}{*}{ P3 } & Adaptif & $\begin{array}{l}\text { Dalam bisnis yang terpenting ada keuntungan, uang masuk lebih besar daripada uang } \\
\text { keluar, [...] "saya seringkali lupa untuk mencatat pengeluaran dan pemasukan, uang } \\
\text { terpakai untuk kepentingan rumah tangga. Manajemen keuangan merupakan hal penting } \\
\text { dalam bisnis, dan saya belum memahaminya dengan baik, saya harus belajar tentang hal } \\
\text { tersebut. }\end{array}$ \\
\hline & Proaktif & $\begin{array}{l}\text { Belajar mengelola keuangan itu mudah, tinggal membuka berbagai aplikasi keuangan } \\
\text { yang ada di google playstore, langsung digunakan dalam bisnis, [...]" saya selalu } \\
\text { menganggap mudah, namun saya tidak pernah mengaplikasikannya, semua nya menjadi } \\
\text { percuma". Sulit, tapi saya memaksakan diri untuk belajar manajemen keuangan minimal } \\
\text { satu jam perhari. }\end{array}$ \\
\hline \multirow[b]{2}{*}{ P4 } & A & $\begin{array}{l}{[\ldots] \text { "Ya, kami belajar dari rutinitas, bagaimana kami menanam, bagaimana kami }} \\
\text { menjual hasil panen, kami belajar dari kebiasaan orang tua dan diri kami sendiri". Tetap } \\
\text { anda harus memahami pasar, selalu berpihak pada konsumen, bukan berpihak pada } \\
\text { kebiasaan diri anda sendiri. Pandemi mengajari saya hal ini. }\end{array}$ \\
\hline & Proaktif & $\begin{array}{l}\text { Saya belajar bahwa bisnis tanpa pengetahuan pasar yang cukup adalah sebuah risiko } \\
\text { yang besar dalam bertani. [...] "gampang lah menjual mah, pasar pasti butuh produk } \\
\text { saya, mereka pasti akan mendatangi saya dengan sendirinya. Ternyata saya salah, } \\
\text { sebaliknya }[\ldots] \text { saya harus memiliki pengetahuan tentang pasar dan saya harus } \\
\text { mencarinya sendiri. }\end{array}$ \\
\hline \multirow[b]{2}{*}{ P5 } & Adaptif & $\begin{array}{l}{[\ldots] \text { "Perencanaan yang matang tidak menjamin semua akan berjalan dengan baik, }} \\
\text { banyak hal yang dapat mengubah rencana kita". Sebagai pengusaha kita harus selalu } \\
\text { mempersiapkan segala sesuatu dengan baik, termasuk sebuah kegagalan }\end{array}$ \\
\hline & Proaktif & $\begin{array}{l}\text { Saya belajar bahwa silaturahmi dalam bisnis menjadi sesuatu yang utama }[\ldots] \\
\text { Silaturahmi mendatangkan rezeki, jadi dalam bisnis kita harus banyak bersilaturahmi } \\
\text { dengan siapapun". Saya harus memiliki jaringan pasar yang luas, selalu mencari peluang } \\
\text { yang dapat membantu saya dalam pengembangan usaha. }\end{array}$ \\
\hline
\end{tabular}

Sumber : Data Primer (data telah ditranslate dari bahasa sunda ke bahasa Indonesia)

\section{KESIMPULAN DAN SARAN}

Sebuah pembelajaran menjadi berharga ketika terjadi perubahan dalam hal keyakinan, cara pandang dan perspektif yang membentuk seorang individu (Cope \& Watts, 2000). Seorang wirausaha belajar dari kesalahan atau kegagalan dengan menggunakan pengalaman ketika bisnis mereka mengalami kerugian atau kebangkrutan (Shepherd, 2003). Sebuah kegagalan selama proses berwirausaha seorang individu dapat menjadi pemicu proses pembelajaran bagi individu tersebut. Pengetahuan baru diperoleh dari hubungan yang kompleks, antara proses refleksi diri yang ditimbulkan dari sebuah kegagalan, proses pembelajaran dan tindakan untuk bangkit dari kegagalan tersebut.

$$
\text { Pembelajaran seperti ini }
$$
mendorong seorang individu untuk mencari keterampilan baru, juga belajar untuk mengembangkan manajemen bisnis nya. Dalam dimensi pembelajaran kewirausahaan, penelitian ini menjelaskan bahwa petani informan sebagai pengusaha telah menjadikan pengalaman sebelumnya sebagai pengetahuan baru untuk memulai dan menjalankan bisnis baru mereka. Mereka menggunakan pengalaman sebelumnya 
untuk membangun bisnis yang lebih adaptif dan mampu menghadapi kendala dan kegagalan yang sebelumnya mereka pernah rasakan. Proses memahami diri sendiri yang dilakukan oleh petani informan menunjukkan proses pendewasaan dalam kehidupan pribadi dan profesional mereka. Dalam kaitannya dengan jaringan dan relasi bisnis, para petani informan telah mempelajari halhal baru, bagaimana mereka harus berhubungan dengan para stakeholder yang terkait dengan aktivitas bisnis dan yang membentuk lingkungan sosial mereka. Terakhir, para petani informan ini juga dapat beradaptasi dengan kondisi yang ada dan secara proaktif berubah mengikuti perubahan yang ada, membuat dirinya "pantas" untuk ikut mencari rezeki dalam bisnis pertanian yang dinamis.

Kontribusi dari penelitian ini bersifat akademis dan praktis. Hasil yang diperoleh diharapkan dapat memberikan kontribusi terhadap proses pembelajaran kewirausahaan dari sebuah kegagalan bisnis. Dari sisi praktis, hasil yang diperoleh diharapkan dapat memberikan pengetahuan bagi seorang wirausahawan, bahwa pembelajaran adalah sesuatu yang berasal dari proses refleksi, sehingga dapat membantu mereka untuk memanfaatkan pengalaman yang dimiliki untuk meningkatkan kapasitas diri sehingga menjadi lebih baik pasca kegagalan bisnis. Keterbatasan dari penelitian ini adalah bersifat eksklusif dalam hubungannya dengan petani informan yang dipilih atas dasar kesediaan mereka untuk diteliti dan kedekatan dengan peneliti. Oleh karena itu, hasil dibatasi pada petani informan dan kesimpulan dari peneliti, sehingga masih sangat terbuka untuk dilakukan penelitian terkait pembelajaran kewirausahaan pada petani-petani lainnya, sebagai sebuah pembelajaran bagi kita semua. Pengetahuan baru mungkin muncul, karena dengan perjalanan waktu, dampak covid 19 mungkin telah hilang, sehingga diperlukan penelitian-penelitian selanjutnya, disesuaikan dengan kondisi lingkungan yang sangat dinamis, mempengaruhi proses bisnis dari seorang wirausahawan.

Saran untuk penelitian selanjutnya, untuk melanjutkan dan memperdalam tema penelitian ini, kami menyarankan untuk mereplikasi studi ini dengan jumlah petani informan yang lebih banyak, sehingga dapat memberikan pengetahuan dan inspirasi baru bagi seorang pengusaha ataupun akademisi, 
dalam menghadapi sebuah kegagalan bisnis serta bagaimana untuk bangkit dari kegagalan tersebut, baik itu dalam sektor pertanian atau pada sektor non pertanian.

\section{DAFTAR PUSTAKA}

Aprilia, A., \& Adianti, V. (2020). Dampak Covid-19 Terhadap Stabilitas Ekonomi Dunia (Studi 14 Negara Berdampak Paling Parah). Jurnal Kajian Ekonomi dan Kebijakan Publik, Vol. 5 No. 2 Juli 2020

Blackburn, R., \& Kovalainen, A. (2009). Researching small firms and entrepreneurship: Past, present and future. International Journal of Management Reviews, 11(2), 127148.

Cope, J. (2003). Entrepreneurial learning and critical reflection: Discontinuous events as triggers for 'higher-level'learning.

Management Learning, 34(4), 429450.

Cope, J. (2005). Toward a dynamic learning perspective of entrepreneurship. Entrepreneurship Theory and Practice, 29(4), 373397.

Cope, J. (2011). Entrepreneurial learning from failure: An interpretative phenomenological analysis. Journal of Business Venturing, 26(6), 604-623.

Cope, J., \& Watts, G. (2000). Learning by doing-an exploration of experience, critical incidents and reflection in entrepreneurial learning. International Journal of Entrepreneurial Behavior \& Research.

Dwiastuti, R. (2017). Metode Penelitian Sosial Ekonomi Pertanian: Dilengkapi Pengenalan Metode
Penelitian Kuantitatif, Kualitatif, dan Kombinasi Kuantitatifkualitatif. Universitas Brawijaya Press.

Fraenkel, J. R., Wallen, N. E., \& Hyun, H. H. (1993). How to design and evaluate research in education (Vol. 7). McGraw-Hill New York.

Frota Vasconcellos Dias, T. R., \& Martens, C. D. P. (2019). Business Failure And The Dimension Of Entrepreneurial Learning: Study With Entrepreneurs Of Micro And Small-Sized Enterprises. Brazilian Journal of Management/Revista de Administração Da UFSM, 12(1).

Grande, J., Madsen, E. L., \& Borch, O. J. (2011). The relationship between resources, entrepreneurial orientation and performance in farm-based ventures. Entrepreneurship and Regional Development, 23(3-4), 89-111.

Jannah, M. (2015). Faktor-Faktor Yang Mempengaruhi Kegagalan Usaha. ISLAMICONOMIC: Jurnal Ekonomi Islam, 6(1).

Kennedy, J., Tennent, B., \& Gibson, B. (2006). Financial management practices in small businesses: Regional and metropolitan. Small Enterprise Research, 14(1), 55-63.

Longenecker, C. O., Simonetti, J. L., \& Sharkey, T. W. (1999). Why organizations fail: The view from the front-line. Management Decision.

Mellahi, K., \& Wilkinson, A. (2004). Organizational failure: A critique of recent research and a proposed integrative framework. International Journal of Management Reviews, 5(1), 21-41.

Minello, I. F., Scherer, L. A., \& da Costa Alves, L. (2014). Entrepreneurial competencies and business failure. International Journal of Entrepreneurship, 18, 1. 
Minniti, M., \& Bygrave, W. (2001). A dynamic model of entrepreneurial learning. Entrepreneurship Theory and Practice, 25(3), 5-16.

Muliati, N. K. (2020). Pengaruh Perekonomian Indonesia di Berbagai Sektor Akibat Corona Virus Disease 2019 (Covid-19). Widya Akuntansi dan Keuangan, 2(2), 78-86. https://doi.org/10.32795/widyaakun tansi.v2i2.874

Politis, D. (2008). Does prior start-up experience matter for entrepreneurs' learning? Journal of Small Business and Enterprise Development.

Robinson, S. (2007). Business failure rates: A look at sex and location. Academy of Entrepreneurship Journal, 13(1), 45-56.

Shepherd, D. A. (2003). Learning from business failure: Propositions of grief recovery for the selfemployed. Academy of Management Review, 28(2), 318328.
Shepherd, D. A., Wiklund, J., \& Haynie, J. M. (2009). Moving forward:

Balancing the financial and emotional costs of business failure. Journal of Business Venturing, 24(2), 134-148.

Toumi, M., \& Smida, A. (2018). Entrepreneurship education: Understanding the failure of entrepreneurial act for learners. International Journal of Technology Management \& Sustainable Development, 17(3), 275-294.

https://doi.org/10.1386/tmsd.17.3.2 $75 \quad 1$

Ucbasaran, D., Shepherd, D. A., Lockett, A., \& Lyon, S. J. (2013). Life after business failure: The process and consequences of business failure for entrepreneurs. Journal of Management, 39(1), 163-202. 